\title{
Synthesis, Antibacterial and Cytotoxic Activities of New Thiazole Based Pyrrolidine Derivatives
}

\author{
Erdal Kocabaş ${ }^{1, * \mathbb{D}}$, Ahmet Burak Sarı̈üney ${ }^{1 \mathbb{D}}$, Fatih Erci ${ }^{2 \mathbb{D}}$, Rabia Çakır-Koç ${ }^{3 \mathbb{D}}$, Hilal Özen \\ Kocabaş ${ }^{4}$, Emrah Torlak ${ }^{5}$ (D), Ahmet Coşkun ${ }^{1}$ (D) \\ 1 Department of Chemistry, Necmettin Erbakan University, Konya-Turkey; ekocabas@erbakan.edu.tr (E.K.), \\ absariguney@erbakan.edu.tr (A.B.S.), acoskun@erbakan.edu.tr (A.C.); \\ 2 Department of Biotechnology, Necmettin Erbakan University, Konya-Turkey; fxerci@ gmail.com (F.E.); \\ Department of Bioengineering, Yıldız Technical University, Istanbul-Turkey; rabiakoc@ yildiz.edu.tr (R.C.-K.); \\ National Education Directorate, Konya-Turkey; hilalozenkocabas@gmail.com (H.O.K.); \\ 5 Department of Molecular Biology and Genetic, Necmettin Erbakan University, Konya-Turkey; etorlak@erbakan.edu.tr \\ (E.T.); \\ * Correspondence: ekocabas@erbakan.edu.tr;
}

Scopus Author ID 8633963300

Received: 2.12.2020; Revised: 29.12.2020; Accepted: 31.12.2020; Published: 3.01.2021

\begin{abstract}
In this study, some thiazole-based pyrrolidine derivatives were synthesized, characterized by FT-IR and ${ }^{1} \mathrm{H}$ NMR spectroscopic techniques, and evaluated as potential antibacterial agents. Their antibacterial activities were evaluated by broth microdilution method and expressed as minimum inhibitory concentration; against Escherichia coli, Salmonella typhimurium, Bacillus cereus, and Staphylococcus aureus. Cytotoxicity studies of synthesized compounds were also conducted to minimize the toxic effects on healthy mammalian cells. From synthesized compounds, 4-F-phenyl derivative compound (11) has been found to inhibit Gram-positive bacteria with minimum toxicity selectively.
\end{abstract}

Keywords: thiazole; pyrrolidine; antibacterial activity; cytotoxicity.

(C) 2020 by the authors. This article is an open-access article distributed under the terms and conditions of the Creative Commons Attribution (CC BY) license (https://creativecommons.org/licenses/by/4.0/).

\section{Introduction}

Although existing for centuries, infectious diseases are still a severe human health problem [1]. Among organisms that cause infectious diseases, bacteria has become one of the most challenging issues in the treatment because the widespread application of antibiotics has caused multidrug-resistant bacteria [2-3]. This drives researchers around the World to work on discovering or develop new and different potent antibacterial compounds. While developing new compounds, besides the antibacterial activity, the toxicity towards healthy mammalian cells is a key factor [4]. Despite all tremendous studies about this area, humans suffer from a lack of effective and safe medicines [5].

Thiazole is part of a class of five-membered heterocyclic compounds with a sulfur and nitrogen atom and has been the subject of many different research types to date [6]. Thiazole derivatives can be seen in nature as thiamine (vitamin- $\mathrm{B}_{1}$ ), penicillin, and luciferin [7]. It has been reported many times in the literature that thiazole and its derivatives possess a broad range of biological activities [8], such as antibacterial, anticancer9, antifungal [10], antiinflammatory [11], anti-tubercular [12], antioxidant [13] activities. In addition to these, pyrrolidine is also a five-membered heterocyclic compound present in alkaloids such as 
nicotine [14] and hygrine [15]. Pyrrolidine derivatives have a variety of biological activities such as antimicrobial [16], anti-HIV [17], anticancer [18], and many more [19].

Keeping these facts in mind, we decided to combine two heterocyclic compounds for antibacterial activity. We synthesized some thiazole derivatives and combined them with pyrrolidine derivatives. After characterizing their structure with FT-IR and 1H NMR techniques, their antibacterial activity was evaluated against Staphylococcus aureus, Bacillus cereus, Salmonella typhimurium, and Escherichia coli. Also, cytotoxicity studies were also conducted with L929 cells to minimize the toxic effects on healthy cells.

\section{Materials and Methods}

\subsection{Synthesis.}

Unless otherwise noted, chemicals were obtained from global suppliers (Merck or Aldrich) and were used without further purification. Solvents were of HPLC or analytical grade, and they were dried with molecular sieves $(3 \AA)$. All melting points were determined with EZ-Melt Automated Melting Point Apparatus. FT-IR spectra were recorded on Thermo Nicolet İS5. ${ }^{1} \mathrm{H}$ NMR spectra were measured on a Varian $400 \mathrm{MHz}$ in DMSO-d6 as a solvent, using tetramethylsilane (TMS) as an internal standard, and chemical shifts are expressed as $\delta$ ppm.

\subsubsection{General procedure for the synthesis of 1,3-thiazole derivatives.}

In a $50 \mathrm{ml}$ single necked flask, $0,005 \mathrm{~mol}$ phenacylbromide and 0,02 mol sodium acetate were added to the solution of $0,005 \mathrm{~mol}$ thiosemicarbazide in $10 \mathrm{~mL}$ ethanol. The reaction mixture was heated under reflux for $6 \mathrm{~h}$, concentrated, and left to cool. The solid was filtered and recrystallized using appropriate solvent mixtures.

\section{4- (4-bromophenyl) -2-hydrazinylthiazole (1).}

$\mathrm{CHCl}_{3} / \mathrm{Hexane}$; Yellow powder; Yield 68\%; m.p.: 117-119 ${ }^{\circ} \mathrm{C} .{ }^{1} \mathrm{H}$ NMR $(400 \mathrm{MHz}$, DMSO-d6, $\left.25^{\circ} \mathrm{C}\right),(\delta: \mathrm{ppm}): 10,45(\mathrm{~s}, 1 \mathrm{H}, \mathrm{NH}) ; 8,80\left(\mathrm{~s}, 2 \mathrm{H}, \mathrm{NH}_{2}\right) ; 7,60-7,85(\mathrm{~m}, 4 \mathrm{H}, \mathrm{Ar}-\mathrm{H})$; 7,10 (s, 1H, CH thiazole). FT-IR: $3310\left(-\mathrm{NH}_{2}\right), 3256(-\mathrm{NH}), 1606(-\mathrm{C}=\mathrm{N}), 1537,1471,1317$, 1200, 1070, 903. 814.

\section{4- (4-chlorophenyl) -2-hydrazinylthiazole (2).}

$\mathrm{CHCl}_{3} / \mathrm{Hexane}$; Yellow powder; Yield 70\%; m.p.: 120-122 ${ }^{\circ} \mathrm{C} .{ }^{1} \mathrm{H}$ NMR (400 MHz, DMSO-d $\left.6,25^{\circ} \mathrm{C}\right),(\delta: \mathrm{ppm}): 10,40(\mathrm{~s}, 1 \mathrm{H}, \mathrm{NH}) ; 8,85\left(\mathrm{~s}, 2 \mathrm{H}, \mathrm{NH}_{2}\right) ; 7,50-7,80(\mathrm{~m}, 4 \mathrm{H}, \mathrm{Ar}-\mathrm{H})$; 7,20 (s, 1H, CH thiazole). FT-IR: $3307\left(-\mathrm{NH}_{2}\right), 3255(-\mathrm{NH}), 1608(-\mathrm{C}=\mathrm{N}), 1539,1476,1417$, $1321,1175,1113,969$.

\section{2-hydrazinyl-4- (3-nitrophenyl) thiazole (3).}

Ethanol; Orange powder; Yield 65\%; m.p.: $138-140{ }^{\circ} \mathrm{C} .{ }^{1} \mathrm{H}$ NMR (400 MHz, DMSO$\left.\mathrm{d}_{6}, 25^{\circ} \mathrm{C}\right),(\delta: \mathrm{ppm}): 10,50(\mathrm{~s}, 1 \mathrm{H}, \mathrm{NH}) ; 8,75\left(\mathrm{~s}, 2 \mathrm{H}, \mathrm{NH}_{2}\right) ; 7,60-7,90(\mathrm{~m}, 4 \mathrm{H}, \mathrm{Ar}-\mathrm{H}) ; 7,15$ (s, $1 \mathrm{H}, \mathrm{CH}$ thiazole). FT-IR: $3365\left(-\mathrm{NH}_{2}\right), 3165(-\mathrm{NH}), 1615(-\mathrm{C}=\mathrm{N}), 1575,1511,1405,1337$, 1259, 1120, 935.

\section{2-hydrazinyl-4- (4-nitrophenyl) thiazole (4).}

Ethanol; Orange powder; Yield 70\%; m.p.: $143-145{ }^{\circ} \mathrm{C} .{ }^{1} \mathrm{H}$ NMR (400 MHz, DMSO$\left.\mathrm{d}_{6}, 25^{\circ} \mathrm{C}\right),(\delta: \mathrm{ppm}): 10,45(\mathrm{~s}, 1 \mathrm{H}, \mathrm{NH}) ; 8,70\left(\mathrm{~s}, 2 \mathrm{H}, \mathrm{NH}_{2}\right) ; 7,55-8,15(\mathrm{~m}, 4 \mathrm{H}, \mathrm{Ar}-\mathrm{H}) ; 7,25$ (s, 1H, $\mathrm{CH}$ thiazole). FT-IR: $3353\left(-\mathrm{NH}_{2}\right), 3236(-\mathrm{NH}), 1627(-\mathrm{C}=\mathrm{N}), 1595,1558,1410,1331$, $1106,959$. 


\section{4- (4-fluorophenyl) -2-hydrazinylthiazole (5).}

Ethanol; Red-brown powder; Yield 60\%; m.p.: 116-118 ${ }^{\circ} \mathrm{C} .{ }^{1} \mathrm{H}$ NMR $(400 \mathrm{MHz}$, DMSO-d6, $\left.25^{\circ} \mathrm{C}\right),(\delta: \mathrm{ppm}): 10,40(\mathrm{~s}, 1 \mathrm{H}, \mathrm{NH}) ; 8,85\left(\mathrm{~s}, 2 \mathrm{H}, \mathrm{NH}_{2}\right) ; 7,65-8,10(\mathrm{~m}, 4 \mathrm{H}, \mathrm{Ar}-\mathrm{H})$; 7,15 (s, 1H, CH thiazole). FT-IR: $3338\left(-\mathrm{NH}_{2}\right), 3207(-\mathrm{NH}), 1630(-\mathrm{C}=\mathrm{N}), 1599,1531,1489$, 1407, 1280, 1116, 917.

\section{3- (2-hydrazinylthiazol-4-yl) -2H-chromen-2-one (6).}

Ethanol; Brown powder; Yield 75\%; m.p.: 178-180 ${ }^{\circ} \mathrm{C} .{ }^{1} \mathrm{H}$ NMR (400 MHz, DMSO$\left.\mathrm{d}_{6}, 25^{\circ} \mathrm{C}\right),(\delta: \mathrm{ppm}): 10,50(\mathrm{~s}, 1 \mathrm{H}, \mathrm{NH}) ; 8,70\left(\mathrm{~s}, 2 \mathrm{H}, \mathrm{NH}_{2}\right) ; 7,60-7,90(\mathrm{~m}, 4 \mathrm{H}, \mathrm{Ar}-\mathrm{H}) ; 7,20(\mathrm{~s}$, 1H, CH thiazole). FT-IR: $3340\left(-\mathrm{NH}_{2}\right), 3236(-\mathrm{NH}), 1604(-\mathrm{C}=\mathrm{N}), 1560,1485,1433,1376$, $1150,927$.

\subsubsection{General procedure for the synthesis of pyrrolidine derivatives of 1,3-thiazoles.}

1,3-thiazole derivative $(0.05 \mathrm{~mol})$ and L-(+)-tartaric acid (0.05 mol) were refluxed in xylene for 8 hours with a Dean-Stark apparatus. The reaction mixture was cooled to ambient temperature, and the resulting crystalline product was filtered off. After washing the crude product with hexane several times, it was recrystallized with ethanol solvent.

(3S-4S) -1 - ((4- (4-bromophenyl) thiazol-2-yl) amino) -3,4-dihydroxypyrrolidine-2,5dione (7).

Light yellow powder; Yield 62\%; m.p.: $188-190{ }^{\circ} \mathrm{C} .{ }^{1} \mathrm{H}$ NMR (400 MHz, DMSO-d6, $\left.25^{\circ} \mathrm{C}\right),(\delta: \mathrm{ppm}): 10,40(\mathrm{~s}, 1 \mathrm{H}, \mathrm{NH}), 7,60-8,30(\mathrm{~m}, 4 \mathrm{H}, \mathrm{Ar}-\mathrm{H}), 7,25$ (s, 1H, CH thiazole), 6,30 (br,2H, OH), 5,00 (d, 2H, CH). FT-IR: $3234(-\mathrm{OH}), 3150(-\mathrm{NH}), 2965,1667$ (-C=O), 1552, 1474, 1397, 1262, 1200, 1132, 1071, 833.

(3S-4S) -1 - ((4- (4-chlorophenyl) thiazol-2-yl) amino) -3,4-dihydroxypyrrolidine-2,5dione (8).

Light yellow powder; Yield 63\%; m.p.: 196-198 ${ }^{\circ} \mathrm{C} .{ }^{1} \mathrm{H}$ NMR (400 MHz, DMSO-d6, $\left.25^{\circ} \mathrm{C}\right),(\delta: \mathrm{ppm}): 10,30(\mathrm{~s}, 1 \mathrm{H}, \mathrm{NH}), 7,55-8,30(\mathrm{~m}, 4 \mathrm{H}, \mathrm{Ar}-\mathrm{H}), 7,20$ (s, 1H, CH thiazole), 6,28 (br,2H, OH), 5,10 (d, 2H, CH). FT-IR: $3235(-\mathrm{OH}), 3148(-\mathrm{NH})$, 2967, $1666(-\mathrm{C}=\mathrm{O})$, 1550, 1403, 1352, 1260, 1076, 865.

(3S-4S) -3,4-dihydroxy-1 - ((4- (3-nitrophenyl) thiazol-2-yl) amino) -pyrrolidine-2,5-dione (9).

Yellow powder; Yield 58\%; m.p.: 201-203 ${ }^{\circ} \mathrm{C} .{ }^{1} \mathrm{H}$ NMR (400 MHz, DMSO-d $6,25{ }^{\circ} \mathrm{C}$ ), ( $\delta: \mathrm{ppm}): 10,45$ (s, 1H, NH), 7,50-8,30 (m, 4H, Ar-H), 7,25 (s, 1H, CH thiazole), 6,36 (br,2H, $\mathrm{OH})$, 5,20 (d, 2H, CH). FT-IR: $3324(-\mathrm{OH}), 3120(-\mathrm{NH}), 1730(-\mathrm{C}=\mathrm{O}), 1555,1412,1343,1260$, $1082,876$.

(3S-4S) -3,4-dihydroxy-1 - ((4- (4-nitrophenyl) thiazol-2-yl) amino) -pyrrolidine-2,5-dione (10).

Yellow powder; Yield 60\%; m.p.: 207-209 ${ }^{\circ} \mathrm{C} .{ }^{1} \mathrm{H}$ NMR (400 MHz, DMSO-d $6,25{ }^{\circ} \mathrm{C}$ ),

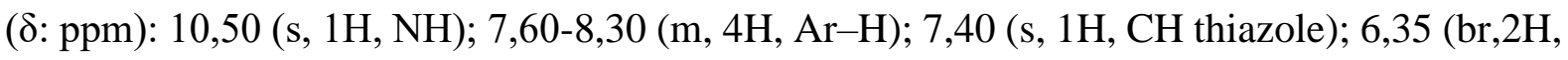
$\mathrm{OH})$; 5,30 (d, 2H, CH). FT-IR: 3320 (-OH), 3115 (-NH), 1732 (-C=O), 1597, 1564, 1507, 1333, 1284, 1108, 851.

(3S-4S) -1 - ((4- (4-fluorophenyl) thiazol-2-yl) amino) -3,4-dihydroxyprolidine-2,5-dione (11).

Light yellow powder; Yield 63\%; m.p.: 193-195 ${ }^{\circ} \mathrm{C} .{ }^{1} \mathrm{H}$ NMR (400 MHz, DMSO-d6, $\left.25^{\circ} \mathrm{C}\right),(\delta: \mathrm{ppm}): 10,55$ (s, 1H, NH); 7,65-8,35 (m, 4H, Ar-H); 7,23 (s, 1H, CH thiazole); 6,26 (br,2H, OH); 5,05 (d, 2H, CH). FT-IR: 3323 (-OH), 3234 (-NH), 2870, $1674(-\mathrm{C}=\mathrm{O}), 1508$, 1417. 1223. 1169, 993. 
(3S,4S)-3,4-dihydroxy-1-((4-(2-oxo-2H-chromen-3-yl)thiazol-2-yl)amino)pyrrolidine-2,5dione (12).

Brown powder, Yield 66\%; m.p.: 211-213 ${ }^{\circ} \mathrm{C} .1 \mathrm{H} \mathrm{NMR}\left(400 \mathrm{MHz}\right.$, DMSO-d $6,25^{\circ} \mathrm{C}$ ),

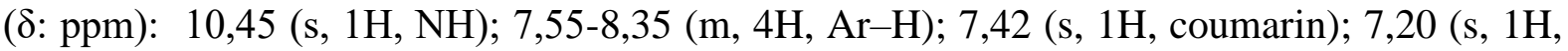
$\mathrm{CH}$ thiazole); 6,26 (br,2H, OH); 5,15 (d, 2H, CH). FT-IR: 3252 (-OH), $3236(-\mathrm{NH}), 1753$ ($\mathrm{C}=\mathrm{O}$ ester $), 1706(-\mathrm{C}=\mathrm{O}), 1567,1487,1452,1258,1010,926$.

\subsection{Antibacterial activity.}

Antibacterial activity of synthesized samples was evaluated by the agar well diffusion method [20]. Both gram-positive Bacillus cereus (ATCC 11778) and Staphylococcus aureus (ATCC 25923), and gram-negative Escherichia coli (ATCC 25922) and Salmonella typhimurium (ATCC 14028) bacteria were used in the study. Lyophilized cultures of bacteria were obtained from Microbiologics Inc. (Saint Cloud, MN, USA). Then, stock cultures of bacteria were prepared in Nutrient Broth containing $20 \%$ glycerol and stored at $-18^{\circ} \mathrm{C}$.

Each microorganism's stock cultures were incubated on Nutrient agar, and then were transferred to tubes containing Mueller Hinton Broth medium and left for 18-24 hours incubation at $37^{\circ} \mathrm{C}$. Then, the bacterial suspensions were adjusted to $0.5 \mathrm{McF}$ arland turbidity representing approximately 1.5 x 108 colony forming units (CFU / mL). McFarland Standards were prepared by using $1 \% \mathrm{H}_{2} \mathrm{SO}_{4}$ and $1.175 \% \mathrm{BaCl}_{2} .2 \mathrm{H}_{2} \mathrm{O}$ stock solutions. The inoculum was spread on Mueller Hinton Agar plates and air-dried at room temperature. A well of approximately $7 \mathrm{~mm}$ diameter was created on the Muller-Hinton Agar plate with the aid of a gel piercing tool. Dimethyl sulfoxide (DMSO) was used to prepare stock solutions of the samples. Furthermore, $50 \mu \mathrm{L}$ aliquots of the compounds with 160 and $400 \mu \mathrm{g}$ concentrations were added to the wells and the substance. Then the diameters of the inhibition zones $(\mathrm{mm})$ around the wells were measured at the end of the 24 -hour incubation at $35^{\circ} \mathrm{C}$. Antibacterial activity of the compounds was determined in comparison to gentamicin (Oxoid, $10 \mu \mathrm{g} / \mathrm{sensidisc}$ antibiotic disc, and the experiments were repeated three times.

\subsection{Cytotoxicity assay.}

L929 cells were used for cytotoxicity experiments. Cells were cultured in T25 flasks with DMEM/F12 medium supplemented with Fetal Bovine Serum 10\% (FBS) and PEST (0.5\% from $10,000 \mathrm{unit} / \mathrm{mL}$ Penicillin $-10 \mathrm{mg} / \mathrm{mL}$ Streptomycin) and incubated at $37^{\circ} \mathrm{C}$. After the culture became confluent, the medium was poured, and $400 \mu 1$ of the trypsin-EDTA enzyme was added. Then cells were incubated at $37^{\circ} \mathrm{C}$ for 5 minutes. After incubation, $5 \mathrm{ml}$ of medium was added, and the cells were centrifuged at $1000 \mathrm{rpm}$ for 5 minutes. Cell number was counted via hemocytometer before experiments.

The toxic effect of compounds on L929 cells was determined by the 2,3-bis-(2methoxy-4-nitro-5-sulfophenyl)-2 H-tetrazolium-5-carboxanilide (XTT) method [21]. XTT is a method that measures metabolic activity. The results obtained in the form of absorbance are directly proportional to cell viability. L929 cells with a concentration of 104 cells/well were seeded in sterile flat-bottom 96-well plates. After 24 hours of incubation at $37^{\circ} \mathrm{C}$, the media was removed, and a fresh medium containing different concentrations of compounds $(0.125$, $0.25,0.5,1,2 \mathrm{mg} / \mathrm{mL}$ ) was added to the cells. Cells were exposed to the substances for 24 hours. Then the medium was replaced with $100 \mu \mathrm{L}$ of $0.5 \mathrm{mg} / \mathrm{mL}$ XTT solution (supplemented with $7.5 \mu \mathrm{g} / \mathrm{mL}$ phenazine methosulfate) in fresh medium. Cells were incubated for $4 \mathrm{~h}$ at 37 
${ }^{\circ} \mathrm{C}$ in $5 \% \mathrm{CO}_{2}$ incubator, and optical density was measured at $450 \mathrm{~nm}$ (Lab-Line multiplate reader).

\section{Results and Discussion}

\subsection{Chemistry.}

Synthesis studies began with the preparation of 1,3-thiazoles via condensation of thiosemicarbazide with acetophenone derivatives as described in the literature [22]. After recrystallization of thiazole derivatives, compounds (1)-(6) obtained. Pyrrolidine derivatives of synthesized thiazole compounds were prepared via their reaction with L-(+)-tartaric acid[23]. Several times, washing of crude product with hexane gave Pyrrolidine derivatives (7)-(12) in moderate yields. The synthetic procedures adopted to obtain the target compounds are given in Scheme 1. The conversion of acetophenone derivatives to thiazoles was depicted in FT-IR spectra by the disappearance of strong carbonyl stretching vibrations around $1700 \mathrm{~cm}^{-}$ 1 . The bands for $-\mathrm{NH}_{2}$ stretching and $\mathrm{C}=\mathrm{N}$ stretching were observed around $3365-3310 \mathrm{~cm}^{-1}$ and $1630-1604 \mathrm{~cm}^{-1}$ regions, respectively. Pyrrolidine derivatives were characterized by $1753-1666$ cm-1 bands that indicate $\mathrm{C}=\mathrm{O}$ groups that come from tartaric acid. The ${ }^{1} \mathrm{H}$ NMR spectra of all compounds displayed singlet signals between $\delta 7.25$ and $7.10 \mathrm{ppm}$ assignable to the $\mathrm{C}-\mathrm{H}$ proton of the thiazole ring as expected. The successful ring closure of thiazole derivatives to pyrrolidine was confirmed with the absence of $\delta 8,80-8,70-\mathrm{NH}_{2}$ singlet. All compounds showed singlet signals between $\delta 10.50-10.30 \mathrm{ppm}$, which correspond to -NH proton near thiazole ring.

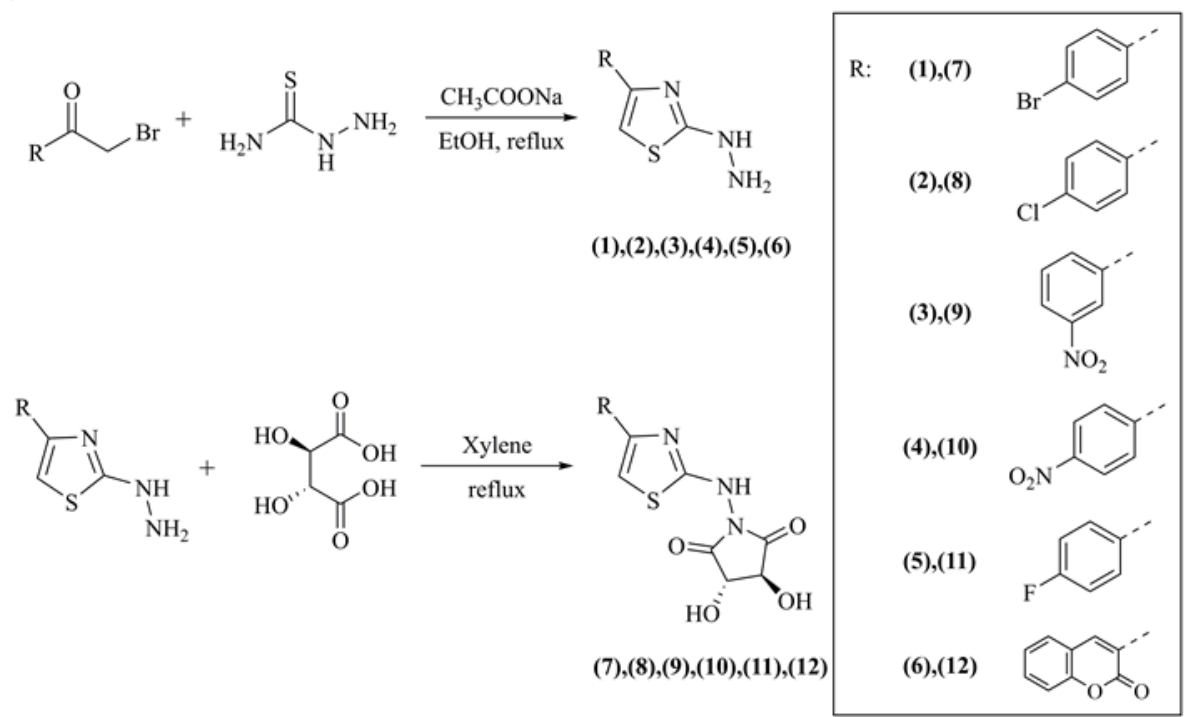

Scheme 1. Synthesis of compounds (1)-(12).

\subsection{Antibacterial activity.}

Table 1. Inhibition zones (diameter) in mm of the compounds against tested bacterial strains.

\begin{tabular}{c|c|c|c|c}
\multirow{2}{*}{ Compounds } & \multicolumn{4}{|c}{ Microorganisms } \\
\cline { 2 - 5 } & $\boldsymbol{E}$. coli & S. typhimurium & B. cereus & S. aureus \\
\hline $\mathbf{( 1 1 )} 160 \mathrm{ug}$ & - & - & $8.97 \pm 0.31$ & - \\
\hline $\mathbf{( 1 1 )} 400 \mu \mathrm{g}$ & - & - & $21.70 \pm 0.36$ & $30.53 \pm 0.42$ \\
\hline Gentamicin 10ug & $21.57 \pm 0.32$ & $24.53 \pm 0.35$ & $22.65 \pm 0.21$ & $22.17 \pm 0.47$
\end{tabular}

${ }^{1}$ The individual data points were expressed in the form of mean \pm standard deviation (mean \pm SD).

- Denotes no antibacterial activity. 
In vitro susceptibilities of selected microorganisms against the compounds were determined by the agar well diffusion method and given in Figure 1. The diameter of the inhibition zone $(\mathrm{mm})$ formed by the compounds as shown in Table 1 . The results revealed that the compound (11) exhibited antibacterial activity against $S$. aureus and B. cereus but did not develop a zone of inhibition against the Gram-negative bacteria E. coli and S. typhimurium. Herein the compound (11) at $400 \mu \mathrm{g}$ concentrations exhibited an inhibition value of $30.53 \pm$ 0.42 and $21.70 \pm 0.36 \mathrm{~mm}$ against $S$. aureus and B. cereus, respectively. The compound (11) at $160 \mu \mathrm{g}$ concentration showed an inhibition zone with $8.97 \pm 0.31 \mathrm{~mm}$ against $B$. cereus. On the other hand, other samples did not show any antibacterial activity.
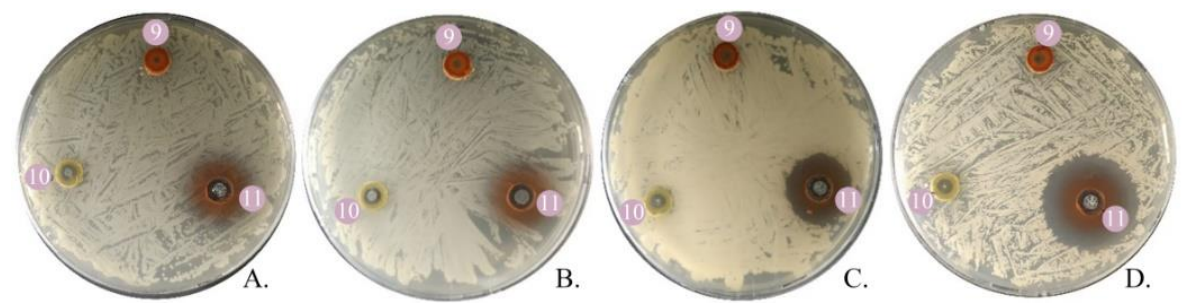

Figure 1. In vitro agar well diffusion studies of compounds (9), (10), (11) against A.) E. coli, B) $S$. typhimurium, C) B. cereus, D) S. aureus.

\subsection{Cytotoxic activity.}

Figure 2 shows the effects of different compounds on the viability of L929 cells. Absorbance values are directly proportional to increasing viability. As seen in the graph, the toxic effect increased with increasing concentrations of the compounds. There are no toxic effects observed at 0.125 and $0.25 \mathrm{mg} / \mathrm{ml}(7),(8)$. The concentration of $0.125 \mathrm{mg} / \mathrm{ml},(11)$ and (12) did not show any toxicity. For other compounds and concentrations, there were proportionately reductions in viability at higher concentrations.

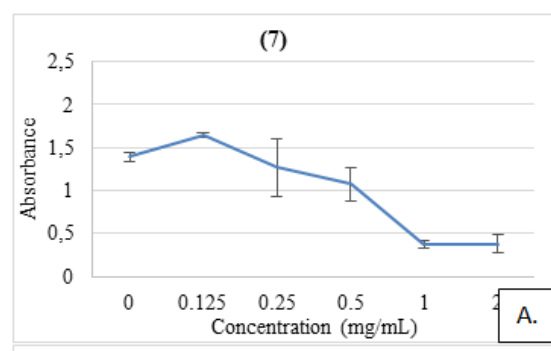

(9)

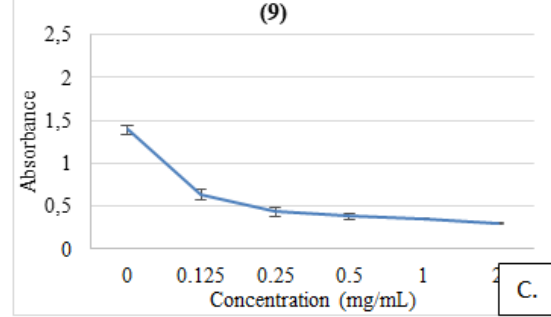

(11)

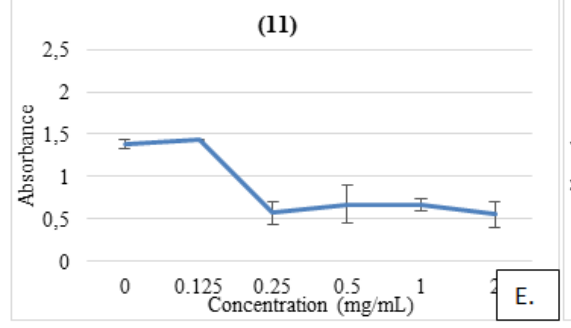

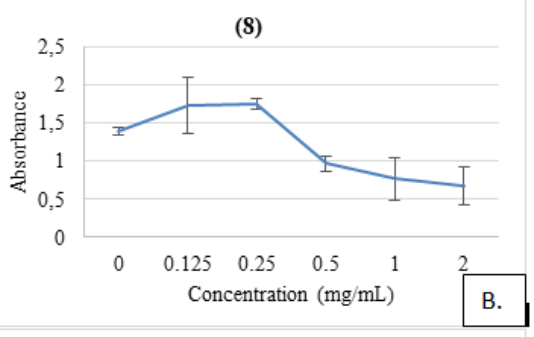

(10)

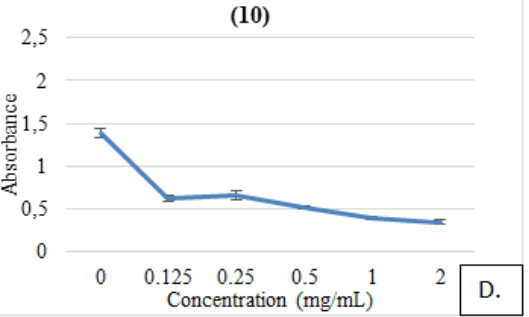

(12)

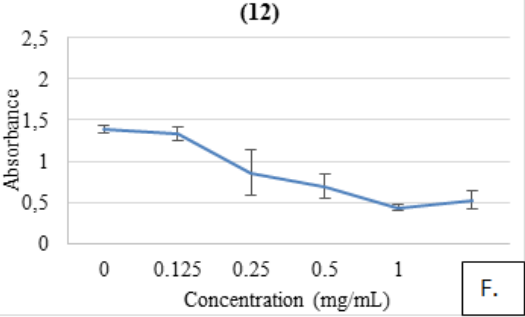

Figure 2. Viability of L929 cells exposed to A.) (7), B.) (8), C.) (9), D.) (10), E.) (11) and F.) (12) with different concentrations. 


\section{Conclusions}

In conclusion, the present study's objective was to synthesize and investigate some thiazole-pyrrolidine derivatives' antibacterial and cytotoxic activities that can serve as promising antibacterial agents. We found that the compound (11) has antibacterial activity against only Gram-positive bacteria. This may be caused by bacteria's structural features, such as different cell wall structures of Gram-negative bacteria and Gram-positive bacteria. As we observed in our previous studies and known in the literature, the outer membrane of Gramnegative bacteria acts as a barrier. It provides for increased tolerance to antimicrobial compounds[24]. Besides, no toxicity effects were observed for compounds (7), (11) at given concentrations. The above results confirmed that combining thiazole and pyrrolidine derivatives as new antibacterial agents were appropriate. Therefore, synthesized compounds in this study will be subjected to further derivatizations for further antimicrobial evaluation.

\section{Funding}

This research was funded by Necmettin Erbakan University Research Projects Board, grant number 171210015.

\section{Acknowledgments}

The authors would like to acknowledge the support of the Necmettin Erbakan University.

\section{Conflicts of Interest}

The authors declare no conflict of interest.

\section{References}

1. Gündüz, M.G.; Uğur, S.B.; Güney, F.; Özkul, C.; Krishna, V.S.; Kaya, S.; Sriram, D.; Doğan, S..D. 1,3Disubstituted urea derivatives: Synthesis, antimicrobial activity evaluation and in silico studies. Bioorganic Chemistry 2020, 102, https://doi.org/10.1016/j.bioorg.2020.104104.

2. Kasare, S.L.; Gund, P.N.; Sathe, B.P.; Patil, P.S.; Rehman, N.N.M.A.; Dixit, P.P.; Choudhari, P.B.; Haval, K.P. Synthesis, antimicrobial screening, and docking study of new 2-(2-ethylpyridin-4-yl)-4-methyl-Nphenylthiazole-5-carboxamide derivatives. Journal of the Chinese Chemical Society 2020, https://doi.org/10.1002/jccs.202000174.

3. Sayed, M.A.; Abdelsalam, H.K.; El-Bassuony, A.A.H. Antimicrobial activity of Novel spinel nanoferrites against pathogenic fungi and bacteria. World Journal of Microbiology and Biotechnology 2020, 36, https://doi.org/10.1007/s11274-020-2803-x.

4. Cuervo-Rodríguez, R.; Muñoz-Bonilla, A.; López-Fabal, F.; Fernández-García, M. Hemolytic and Antimicrobial Activities of a Series of Cationic Amphiphilic Copolymers Comprised of Same Centered Comonomers with Thiazole Moieties and Polyethylene Glycol Derivatives. Polymers 2020, 12, https://doi.org/10.3390/polym12040972.

5. Shaaban, M.R.; Farghaly, T.A.; Alsaedi, A.M.R. Synthesis, Antimicrobial and Anticancer Evaluations of Novel Thiazoles Incorporated Diphenyl Sulfone Moiety. Polycyclic Aromatic Compounds 2020, 1-17, https://doi.org/10.1080/10406638.2020.1837887.

6. Eryılmaz, S.; Türk Çelikoğlu, E.; İdil, Ö.; İnkaya, E.; Kozak, Z.; Mısır, E.; Gül, M. Derivatives of pyridine and thiazole hybrid: Synthesis, DFT, biological evaluation via antimicrobial and DNA cleavage activity. Bioorganic Chemistry 2020, 95, https://doi.org/10.1016/j.bioorg.2019.103476.

7. Hananya, N.; Shabat, D. A Glowing Trajectory between Bio- and Chemiluminescence: From LuciferinBased Probes to Triggerable Dioxetanes. Angewandte Chemie International Edition 2017, 56, 16454-16463, https://doi.org/10.1002/anie.201706969.

8. Chen, K.; Yao, X.; Tang, T.; Chen, L.-M.; Xiao, C.; Wang, J.-Y.; Chen, H.-F.; Jiang, Z.-X.; Liu, Y.; Zheng, $\mathrm{X}$. Thiazole-based and thiazolidine-based protein tyrosine phosphatase 1B inhibitors as potential antidiabetes agents. Medicinal Chemistry Research 2020, 1-16. 
9. Sayed, A.R.; Gomha, S.M.; Taher, E.A.; Muhammad, Z.A.; El-Seedi, H.R.; Gaber, H.M.; Ahmed, M.M. One-Pot Synthesis of Novel Thiazoles as Potential Anticancer Agents. Drug design, development and therapy 2020, 14, 1363-1375, https://doi.org/10.2147/DDDT.S221263.

10. Lino, C.I.; Gonçalves de Souza, I.; Borelli, B.M.; Silvério Matos, T.T.; Santos Teixeira, I.N.; Ramos, J.P.; Maria de Souza Fagundes, E.; de Oliveira Fernandes, P.; Maltarollo, V.G.; Johann, S.; de Oliveira, R.B. Synthesis, molecular modeling studies and evaluation of antifungal activity of a novel series of thiazole derivatives. European Journal of Medicinal Chemistry 2018, 151, 248-260, https://doi.org/10.1016/j.ejmech.2018.03.083.

11. Maghraby, M.T.E.; Abou-Ghadir, O.M.F.; Abdel-Moty, S.G.; Ali, A.Y.; Salem, O.I.A. Novel class of benzimidazole-thiazole hybrids: The privileged scaffolds of potent anti-inflammatory activity with dual inhibition of cyclooxygenase and 15-lipoxygenase enzymes. Bioorganic \& Medicinal Chemistry 2020, 28, https://doi.org/10.1016/j.bmc.2020.115403.

12. Dhameliya, T.M.; Tiwari, R.; Banerjee, A.; Pancholia, S.; Sriram, D.; Panda, D.; Chakraborti, A.K. Benzo[d]thiazole-2-carbanilides as new anti-TB chemotypes: Design, synthesis, biological evaluation, and structure-activity relationship. European Journal of Medicinal Chemistry 2018, 155, 364-380, https://doi.org/10.1016/j.ejmech.2018.05.049.

13. Grozav, A.; Porumb, I.-D.; Găină, L.I.; Filip, L.; Hanganu, D. Cytotoxicity and Antioxidant Potential of Novel 2-(2-((1H-indol-5yl)methylene)-hydrazinyl)-thiazole Derivatives. Molecules 2017, 22, https://doi.org/10.3390/molecules22020260.

14. Robertson, P. A.; Villani, L.; Martin, D.; Robertson, E. G., Laser spectroscopy of nicotine and related analogues: perturbations and puckering in pyridine and pyrrolidine rings. 2020; https://doi.org/10.32655/ASC_8-10_Dec2020.4.

15. Shirsat, R. P.; Imran, S.; Deepak, K.K. A report on identification of a unique hygrine like compound from chloroform extract of Anisochilus carnosus (Lf) Wall. Drug Discovery 2020, 14, 130-134.

16. Lin, J.-L.; Liang, Y.-Q.; Liao, X.-J.; Yang, J.-T.; Li, D.-C.; Huang, Y.-L.; Jiang, Z.-H.; Xu, S.-H.; Zhao, B.X. Acanthophoraine A, a new pyrrolidine alkaloid from the red alga Acanthophora spicifera. Natural Product Research 2020, 34, 2065-2070, https://doi.org/10.1080/14786419.2019.1569008.

17. Li, Z.; Wang, X.; Lin, Y.; Wang, Y.; Wu, S.; Xia, K.; Xu, C.; Ma, H.; Zheng, J.; Luo, L.; Zhu, F.; He, S.; Zhang, X. Design, synthesis, and evaluation of pyrrolidine based CXCR4 antagonists with in vivo anti-tumor metastatic activity. European Journal of Medicinal Chemistry 2020, 205, https://doi.org/10.1016/j.ejmech.2020.112537.

18. Ji, J.; Sajjad, F.; You, Q.; Xing, D.; Fan, H.; Reddy, A.G.K.; Hu, W.; Dong, S. Synthesis and biological evaluation of substituted pyrrolidines and pyrroles as potential anticancer agents. Archiv der Pharmazie 2020, 353, https://doi.org/10.1002/ardp.202000136.

19. Sreekanth, K.; Jha, A. Microwave Assisted Synthesis and Antimicrobial Activity of Novel Pyrrolidine Derivatives. Russian Journal of General Chemistry 2020, 90, 129-134, https://doi.org/10.1134/s107036322001020x.

20. Erci, F.; Cakir-Koc, R.; Isildak, I. Green synthesis of silver nanoparticles using Thymbra spicata L. var. spicata (zahter) aqueous leaf extract and evaluation of their morphology-dependent antibacterial and cytotoxic activity. Artificial Cells, Nanomedicine, and Biotechnology 2018, 46, 150-158, https://doi.org/10.1080/21691401.2017.1415917.

21. Kokcu, Y.; Kecel-Gunduz, S.; Budama-Kilinc, Y.; Cakir-Koc, R.; Bicak, B.; Zorlu, T.; Ozel, A.E.; Akyuz, S. Structural analysis, molecular dynamics and docking calculations of skin protective tripeptide and design, characterization, cytotoxicity studies of its PLGA nanoparticles. Journal of Molecular Structure 2020, 1200, https://doi.org/10.1016/j.molstruc.2019.127046.

22. Bondock, S.; Khalifa, W.; Fadda, A.A. Synthesis and antimicrobial evaluation of some new thiazole, thiazolidinone and thiazoline derivatives starting from 1-chloro-3,4-dihydronaphthalene-2-carboxaldehyde. European Journal of Medicinal Chemistry 2007, 42, 948-954, https://doi.org/10.1016/j.ejmech.2006.12.025.

23. Arslan, M.; Şentürk, M.; Fidan, İ.; Talaz, O.; Ekinci, D.; Coşgun, S.; Supuran, C.T. Synthesis of 3,4dihydroxypyrrolidine-2,5-dione and 3,5-dihydroxybenzoic acid derivatives and evaluation of the carbonic anhydrase I and II inhibition. Journal of Enzyme Inhibition and Medicinal Chemistry 2015, 30, 896-900, https://doi.org/10.3109/14756366.2014.983917.

24. Nikaido, H. Outer membrane barrier as a mechanism of antimicrobial resistance. Antimicrobial Agents and Chemotherapy 1989, 33, https://doi.org/10.1128/aac.33.11.1831. 